\title{
COMPATIBILITY OF Metarhizium anisopliae WITH LIPOSOLUBLE PHOTOPROTECTANTS AND PROTECTIVE EFFECT EVALUATION AGAINST SOLAR RADIATION
}

\author{
COMPATIBILIDADE DE Metarhizium anisopliae COM FOTOPROTETORES \\ LIPOSSOLÚVEIS E AVALIAÇÃO DO EFEITO PROTETOR CONTRA A RADIAÇÃO \\ SOLAR
}

\author{
Dinalva Alves MOCHI'; Antonio Carlos MONTEIRO'; \\ Rosemeire Cristina Linhari Rodrigues PIETRO', Marcos Antonio CORRÊA ${ }^{2}$, \\ José Carlos BARBOSA ${ }^{3}$
}

1. Department of Plant Production. dmochi@ hotmail.com; 3. Department of Mathematical Sciences, Faculty of Agrarian and Veterinary Sciences - Sao Paulo State University, Jaboticabal, Brazil; 2. Department of Drugs and Medicines, Faculty of Pharmaceutical Sciences Sao Paulo State University, Araraquara, Brazil.

\begin{abstract}
The aim of this study was to analyze the compatibility of the Metarhizium anisopliae JAB 68 isolate with liposoluble photoprotectants and the photoprotection conferred to its conidia. The fungus was cultivated in a medium with the photoprotectants Neo Heliopan ${ }^{\circledR}$ BB, Neo Heliopan ${ }^{\circledR}$ E 1000, Eusolex ${ }^{\circledR} 6007$ and Neo Heliopan ${ }^{\circledR}$ AV in various concentrations. Vegetative growth, sporulation and germination were assessed to determine compatibility. Then, conidia were suspended in oil containing the compatible photoprotectants, in their respective concentrations, and exposed to 0-7 hours of light from a solar simulator operating at $1,000 \mathrm{~W} \mathrm{~m}^{-2}$. Neo Heliopan $\mathrm{BB}^{\circledR}$ and Neo Heliopan ${ }^{\circledR}$ E 1000 were compatible with M. anisopliae at $2 \%$ and $1 \%$, respectively. Eusolex ${ }^{\circledR} 6007$ and Neo Heliopan ${ }^{\circledR}$ AV were compatible up to $8 \%$ a $7 \%$, respectively. Conidia exposed to radiation from the solar simulator, with photoprotectant-free oil as its carrier, presented germination of $78.12 \%$ after five hours. When adding any photoprotectant to the conidia oily suspension, the germination percentage was always higher than that obtained in the control. Neo Heliopan ${ }^{\circledR}$ BB at 1 and $2 \%$ and Neo Heliopan $^{\circledR} \mathrm{AV}$ at $0.5 \%$ increased the germination. After 7 hours of exposure the germination percentages were 93.77 , 94.55 and $98.82 \%$, respectively. Eusolex ${ }^{\circledR} 6007$ was not as efficient as previous products, but in the same exposure period was able to protect the conidia $(88.60 \%$ germination) when used at a $1 \%$ concentration. Adding photoprotectants in oily formulations of $M$. anisopliae protects against the harmful effects of UV radiation contributing to the fungus efficiency in the field.
\end{abstract}

KEYWORDS: Microbial control. Entomopathogenic fungus. Sunlight. Photoprotection. UV radiation.

\section{INTRODUCTION}

The use of biological control agents is one of the most promising options to reduce the environmental impact caused by the use of chemical products for pest control. One of the greatest obstacles to the successful use of entomopathogenic fungi in the control of pest insects is solar radiation sensitivity (LOONG et al., 2013). The ultraviolet (UV) rays can reduce the effectiveness of the fungi used in biological control (GHAJAR et al., 2006).

The Metarhizium anisopliae fungus is an important agent for biological control of insects, and has agricultural and veterinary importance. However, the virtual nonexistence of formulations of this bioagent is one of the greatest problems for its use. A large number of studies report the pathogenic activity of bioagents for pest insects, on the other hand, few authors consider microorganism formulations for commercial application (HYNES; BOYETCHKO 2006). The expansion of microbial control programs depends on large-scale production and formulation of micro-organisms (BATISTA FILHO et al., 2001).

The choice of an appropriate photoprotectant to compose the formulation of a bioproduct must take into account its solubility in the formulated product. Oil-based products are preferred because they are more adherent, and are, therefore, less easily removed by water (FONSECA; PRISTA, 2000). Because they are easy to mix and apply, B. bassiana and M. anisopliae conidia mixed in oil are more persistent in the environment (BUKHARI et al., 2011). Conidia mixed in oil were able to induce higher insect mortality than conidia mixed in water (KAAYA, 2000; MARANGA et al., 2005). SANTI et al. (2011) found that soybean oil improved the performance of $M$. anisopliae, making it capable of reaching various phases of Dysdercus peruvianus, a major pest of cotton. In addition to increasing the performance and persistence, studies report that the oils used in the formulations may give the conidia protection against ultraviolet radiation (INGLIS et al, 1995; ALVES et al, 1998). 
Photoprotectants are defined as agents that reduce the effect of UV radiation through mechanisms of absorption, reflection or scattering of this radiation (CABRAL et al., 2011). Chemical photoprotectants are molecules which absorb ultraviolet radiation at a wavelength between 290 and $400 \mathrm{~nm}$ (UVA-UVB), preventing their action. Some are available on the market as liposoluble photoprotectants, which, besides being stable, present broad-spectrum protection (UVA and UVB), high efficiency and excellent water resistance (GALENA, 2007). Therefore, they are ideal for bioproduct formulations. However, they must be compatible with the microorganism used in the formulation. One of the first steps in the development of a mico-insecticide formulation is to evaluate the products' effect on the fungus, to select compatible components (ALVES et al., 2002).

With the aim of increasing the Metarhizium anisopliae conidia protection against solar radiation, this study analyzed the compatibility of the JAB 68 isolate of the fungus with liposoluble photoprotectants and the photoprotection conferred to the conidia.

\section{MATERIAL AND METHODS}

\section{Fungus and photoprotectants}

The Metarhizium anisopliae JAB 68 isolate, pathogenic to larvae and adult Haematobia irritans (MOCHI et al., 2009; 2010a; 2010b) was used. The isolate was previously designated E9 but after genetic identification performed by genetic sequencing of ITS1-5.8S-ITS2 region was renamed. The sequences were deposited in GenBank with the following encodings: KF958306 M. anisopliae JAB 68. Culture stock of the fungus was kept in the collection of the Microbiology Laboratory of the Plant Production Department, Faculty of Agrarian and Veterinary Sciences, São Paulo State University. The isolate was grown in Petri dishes containing a potato dextrose agar (PDA) culture medium, placed in an incubator at $27 \pm 0.5^{\circ} \mathrm{C}$ for 15 days in the dark.

Information about the photoprotectants, their chemical composition and concentrations used are shown in Table 1 . They are synthetic substances used in commercial formulations of sunscreens.

Table 1. Liposoluble photoprotectants used in the study with isolate JAB 68 of Metarhizium anisopliae.

\begin{tabular}{llll}
\hline Trade name & Chemical composition / INCI* & Concentration used & $\begin{array}{l}\text { Range of } \\
\text { protection }\end{array}$ \\
\hline Neo Heliopan ${ }^{\circledR}$ BB & $\begin{array}{l}\text { 2-hydroxy-4-methoxybenzophenone / } \\
\text { Benzophenone-3 }\end{array}$ & $0.5 ; 1 ; 2 ; 4 ; 6 \%$ & UVA/UVB \\
Neo Heliopan ${ }^{\circledR}$ E 1000 & $\begin{array}{l}\text { Isoamyl p-Methoxycinnamate /isoamyl p- } \\
\text { methoxynnamate }\end{array}$ & $0.5 ; 1 ; 2 ; 4 ; 6 ; 8 ; 10 \%$ & UVB \\
Neo Heliopan ${ }^{\circledR}$ AV & $\begin{array}{l}\text { 2-ethylhexyl p-methoxycinnamate / } \\
\text { Octyl Methoxycinnamate }\end{array}$ & $0.5 ; 1 ; 2 ; 3 ; 5 ; 7 \%$ & UVA/UVB \\
Eusolex ${ }^{\circledR} 6007$ & Ethylhexyl dimethyl PABA / PABA & $0.5 ; 1 ; 2 ; 4 ; 6 ; 8 \%$ & UVB \\
\hline
\end{tabular}

*INCI: International Nomenclature Cosmetic Ingredients

\section{Compatibility of Metarhizium anisopliae with liposoluble photoprotectants}

The fungal isolate was inoculated in Pontecorvo minimal medium (PONTECORVO et al, 1953.) with the following composition: $6.0 \mathrm{~g}$ $\mathrm{NaNO}_{3} ; 1.52 \mathrm{~g} \mathrm{KH}_{2} \mathrm{PO}_{4} ; 0.52 \mathrm{~g} \mathrm{MgSO}_{4} 7 \mathrm{H}_{2} \mathrm{O} ; 0.52 \mathrm{~g}$ $\mathrm{KCl} ; 0.01 \mathrm{~g} \mathrm{FeSO}_{4} ; 0.01 \mathrm{~g} \mathrm{ZnSO}_{4} ; 10$ g glucose; 15 $\mathrm{g}$ agar and $1000 \mathrm{ml}$ of deionized water. Glucose was replaced by vegetable oil (soybean oil) $\left(10 \mathrm{ml} \mathrm{l}^{-1}\right)$ emulsified with Alkamuls ${ }^{\circledR}\left(3 \% \mathrm{v} \mathrm{v}^{-1}\right)$ and the photoprotectant was added to the oil. The compatibility of Alkamuls ${ }^{\circledR}$ with the fungus was determined in pre-testing. All the products were added to the liquified medium at the temperature close to $45^{\circ} \mathrm{C}$, thus avoiding alterations of their properties. After poured and solidified into Petri dishes the medium was inoculated by piercing in a central point using a platinum needle previously bathed in a suspension containing $10^{7}$ conidia $\mathrm{ml}^{-1}$ obtained from 15 days old colonies of the fungus. The dishes were placed in an incubator at $27 \pm 0.5^{\circ}$ $\mathrm{C}$ in the dark.

Fungus performance was analyzed according to the following parameters: vegetative growth of the colonies, sporulation and germination of conidia. For each parameter examined, a control was made, with no product added to the growth medium. Vegetative growth was quantified by measurements, in millimeters, of two equidistant diameters previously marked on the outside of the bottom of the Petri dishes. Colony growth measurements were taken every three days until the 18th day after inoculation. Each dish corresponded to a repetition, and each treatment was replicated four times.

Sporulation was evaluated by collecting one sample from the center of each fungal colony, one from the inner area and the other from the periphery 
of the colony, with the aid of a 8-mm diameter metal ring, on the 18th day of incubation. Four replicate colonies were used for the sample collection. These samples were transferred to individual test tubes containing $10 \mathrm{ml}$ sterilized mixture $(1: 1)$ of $\mathrm{NaCI}$ solution $\left(0.89 \% \mathrm{p} \mathrm{v}^{-1}\right)$ and Tween $80^{\circledR}\left(0.1 \% \mathrm{v} \mathrm{v}^{-1}\right)$. After vigorous shaking in an electric tube shaker, the conidia were counted with the aid of a Neubauer chamber under a 400x magnification optical microscope. The amount of conidia produced by the whole colony was calculated based on the values obtained.

Germination was evaluated by direct examination of conidia on the microscope slide. After marking three areas on one side of the slide, the other side was covered with $4 \mathrm{ml}$ of Pontecorvo minimal medium containing emulsified vegetable oil as described, and a photoprotectant in one of the respective concentrations. Next, the slide was placed in Petri dish with high relative humidity, maintained by two wads of cotton moistened with distilled water. Two toothpicks were arranged horizontally under slide to avoid touching the bottom of the dish. One drop (approximately $0.05 \mathrm{ml}$ ) of fungal suspension containing $10^{6}$ conidia $\mathrm{ml}^{-1}$ was inoculated over the part of the culture medium corresponding to each previously marked area. Three replicate slides were used for each treatment. The dishes were kept at $27 \square 0.5^{\circ} \mathrm{C}$ for 15 hours, in darkness. One hundred and fifty conidia were then observed per area, germinated and non-germinated, obtaining the percentage of viable conidia. Conidia with germ tubes equal to or greater than the length of conidium were considered germinated.

To determine the toxic effect of the products, the formula proposed by ROSSI-ZALAF et al. (2008) containing the vegetative growth, sporulation and germination parameters was used:

$\mathrm{BI}=\frac{47[\mathrm{VG}]+43[\mathrm{SP}]+10[\mathrm{GER}]}{100}$

In which:

$\mathrm{BI}=$ Biological Index; $\mathrm{VG}=$ vegetative growth percentage of the colony after 18 days of incubation, in relation to the control; $\mathrm{SP}=$ sporulation percentage after 18 days of incubation, in relation to the control; GER = germination percentage of the conidia after $15 \mathrm{~h}$ of incubation, in relation to the control. No decimals were used to calculate the BI

With the values obtained from the BI, the toxicological classification of the products was made, in the different concentrations, according to the scale established by ROSSI-ZALAF et al. (2008): from 0 to 41 - toxic; from 42 to $66-$ moderately toxic; $>66$ - compatible.

\section{Photoprotection test}

Based on the compatibility tests results, three photoprotectants were selected for the photoprotection test, at $0.5 \%, 1.0 \%$ and $2.0 \%$ concentrations. Conidia of the fungus were suspended in $7 \mathrm{ml}$ of vegetable oil (soybean oil) containing one photoprotectant in one of the concentrations to be tested. After vigorous shaking, the oily suspension was transferred to a sterilized Petri dish $(40 \mathrm{x} 40 \mathrm{~mm})$ and exposed to light from an Oriel solar simulator ${ }^{\circledR}$, model 68.820 , Strafford, CT, USA, with irradiance of $1,000 \mathrm{~W} \mathrm{~m}^{-2}$ in the spectral region region of 250-2,400 $\mathrm{nm}$. During exposure, the assessed dishes were placed inside larger Petri dishes (diameter $150 \mathrm{~mm}$ ), which contained ice to avoid heating of the contents by the infrared radiation. Irradiation was performed at room temperature $\left(25\right.$ to $27^{\circ} \mathrm{C}$ ) and the distance between the exposed suspension and the source of light was $17 \mathrm{~cm}$. The control consisted of an oily suspension of conidia with no photoprotectant. Suspension samples of $0.5 \mathrm{ml}$ were collected at $0,0.5,1,2,3,4$, 5, 6 and 7 hours after irradiation, and tested for conidia germination. Two drops of the irradiated oily suspension were spread, with the help of a Drigalsky spatula, on the surface of the PDA medium placed on the microscopy slides in Petri dishes as described above. After incubation at $27 \square$ $0.5^{\circ} \mathrm{C}$ for 24 hours, in darkness, 150 conidia were examined in each of the three areas previously marked on the slide. Germinated and nongerminated conidia were observed to obtain the percentage of viable conidia. Conidia with germ tubes equal to or greater than the length of conidium were considered germinated.

\section{Statistical analysis}

To assess the compatibility of the fungus with each product, in the respective concentrations, a completely randomized design was used. In the photoprotection test, the experiment was analyzed according to a split-plot in time design, considering the photoprotectants as the main treatment and the periods of exposure (in hours) as secondary treatment.

In all the tests, the data were submitted to variance analysis by the F-test and the means were compared by the Tukey test at a $5 \%$ probability. To carry out the analyses, the AgroEstat program (BARBOSA; MALDONADO 2010) was used. 


\section{RESULTS AND DISCUSSION}

\section{Compatibility of Metarhizium anisopliae with liposoluble photoprotectants}

The Eusolex ${ }^{\circledR} 6007$ and Neo Heliopan ${ }^{\circledR}$ AV photoprotectants were compatible with $M$. anisopliae in all concentrations, in other words, up to $8,0 \%$ and $7,0 \%$, respectively, and Neo Heliopan ${ }^{\circledR}$
MOCHI, D. A. et al

BB and Neo Heliopan ${ }^{\circledR}$ E 1000 were compatible with the fungus only up to $2.0 \%$ and $1 \%$ concentrations, respectively. It is important to note that the four products were tested in larger concentrations, but even so, no product was classified as toxic to the fungus, being classified as moderately toxic (Table 2).

Table 2. Compatibility of isolate JAB 68 of Metarhizium anisopliae with liposoluble photoprotectants in various concentrations, and toxicological classification of product.

\begin{tabular}{|c|c|c|c|c|c|}
\hline $\begin{array}{l}\text { Photoprotectants and } \\
\text { concentrations }(\%)\end{array}$ & $\begin{array}{l}\text { Grow } \\
(\mathrm{mm})\end{array}$ & $\begin{array}{l}\text { Sporulation } \\
\text { (x } 10^{9} \text { con./col.) }\end{array}$ & $\begin{array}{c}\text { Germination } \\
(\%)\end{array}$ & $\begin{array}{l}\text { Biological } \\
\text { Index }\end{array}$ & $\begin{array}{l}\text { Toxicological } \\
\text { Classification }\end{array}$ \\
\hline \multicolumn{6}{|l|}{ Neo Heliopan ${ }^{\circledR}$ BB } \\
\hline Control & $64.25 \pm 1.03 \mathrm{a}$ & $2.19 \pm 0.22 \mathrm{a}$ & $99.80 \pm 0.11 \mathrm{a}$ & & \\
\hline 0.5 & $62.00 \pm 0.40 \mathrm{abc}$ & $1.97 \pm 0.14 \mathrm{a}$ & $99.50 \pm 0.40 \mathrm{a}$ & 94 & Compatible \\
\hline 1.0 & $62.75 \pm 1.10 \mathrm{ab}$ & $1.77 \pm 0.05 \mathrm{a}$ & $99.26 \pm 0.16 \mathrm{a}$ & 91 & Compatible \\
\hline 2.0 & $62.50 \pm 0.86 \mathrm{abc}$ & $0.91 \pm 0.06 \mathrm{~b}$ & $99.10 \pm 0.11 \mathrm{a}$ & 74 & Compatible \\
\hline 4.0 & $59.75 \pm 0.94 \mathrm{bc}$ & $0.46 \pm 0.03 \mathrm{~b}$ & $99.13 \pm 0.26 \mathrm{a}$ & 63 & Mod. toxic \\
\hline 6.0 & $58.75 \pm 0.47 \mathrm{c}$ & $0.65 \pm 0.12 b$ & $99.83 \pm 0.06 \mathrm{a}$ & 64 & Mod. toxic \\
\hline F Test & $5.88 * *$ & $37.53 * *$ & $2.47^{\mathrm{NS}}$ & & \\
\hline C.V. $(\%)$ & 0.60 & 2.08 & 2.03 & & \\
\hline \multicolumn{6}{|l|}{ Neo Heliopan ${ }^{\circledR}$ E 1000} \\
\hline Control & $50.25 \pm 1.03 \mathrm{a}$ & $3.30 \pm 0.54 \mathrm{a}$ & $99.46 \pm 0.27 \mathrm{a}$ & & \\
\hline 0.5 & $44.00 \pm 1.29 \mathrm{~b}$ & $2.36 \pm 0.58 \mathrm{ab}$ & $99.43 \pm 0.27 \mathrm{a}$ & 82 & Compatible \\
\hline 1.0 & $35.25 \pm 0.85 \mathrm{c}$ & $1.93 \pm 0.40 \mathrm{ab}$ & $99.63 \pm 0.27 \mathrm{a}$ & 68 & Compatible \\
\hline 2.0 & $35.50 \pm 0.28 \mathrm{c}$ & $1.52 \pm 0.18 \mathrm{ab}$ & $99.73 \pm 0.06 \mathrm{a}$ & 63 & Mod. Toxic \\
\hline 4.0 & $34.00 \pm 0.91 \mathrm{c}$ & $1.84 \pm 0.13 \mathrm{ab}$ & $99.63 \pm 0.16 \mathrm{a}$ & 66 & Mod. Toxic \\
\hline 6.0 & $29.75 \pm 0.47 \mathrm{~d}$ & $1.30 \pm 0.17 \mathrm{~b}$ & $99.73 \pm 0.13 \mathrm{a}$ & 55 & Mod. Toxic \\
\hline 8.0 & $27.50 \pm 0.86 \mathrm{~d}$ & $2.18 \pm 0.35 \mathrm{ab}$ & $99.86 \pm 0.06 \mathrm{a}$ & 64 & Mod. Toxic \\
\hline 10.0 & $28.50 \pm 0.50 \mathrm{~d}$ & $1.42 \pm 0.41 \mathrm{~b}$ & $99.46 \pm 0.16 \mathrm{a}$ & 55 & Mod. Toxic \\
\hline F Test & $84.43 * *$ & $2.72 * *$ & $0.53^{\mathrm{NS}}$ & & \\
\hline C.V. $(\%)$ & 1.09 & 5.51 & 2.22 & & \\
\hline \multicolumn{6}{|l|}{ Neo Heliopan ${ }^{\circledR}$ AV } \\
\hline Controle & $53.75 \pm 0.85 \mathrm{a}$ & $6.76 \pm 0.39 \mathrm{a}$ & $99.50 \pm 0.20 \mathrm{a}$ & & \\
\hline 0.5 & $51.50 \pm 0.64 \mathrm{abc}$ & $4.63 \pm 0.44 \mathrm{ab}$ & $99.56 \pm 0.14 \mathrm{a}$ & 84 & Compatible \\
\hline 1.0 & $50.50 \pm 0.28 \mathrm{abcd}$ & $3.44 \pm 0.67 \mathrm{~b}$ & $99.40 \pm 0.10 \mathrm{a}$ & 76 & Compatible \\
\hline 2.0 & $50.00 \pm 0.40 \mathrm{bcd}$ & $4.32 \pm 0.67 \mathrm{ab}$ & $99.23 \pm 0.06 \mathrm{a}$ & 76 & Compatible \\
\hline 3.0 & $48.25 \pm 1.10 \mathrm{~d}$ & $4.31 \pm 0.24 \mathrm{ab}$ & $99.56 \pm 0.14 \mathrm{a}$ & 80 & Compatible \\
\hline 5.0 & $49.00 \pm 0.40 \mathrm{~cd}$ & $3.57 \pm 0.77 \mathrm{~b}$ & $99.03 \pm 0.17 \mathrm{a}$ & 80 & Compatible \\
\hline 7.0 & $52.50 \pm 0.86 \mathrm{ab}$ & $5.93 \pm 0.30 \mathrm{ab}$ & $99.03 \pm 0.34 \mathrm{a}$ & 79 & Compatible \\
\hline F Test & $7.32 * *$ & $4.22 * *$ & $1.56^{\mathrm{NS}}$ & & \\
\hline C.V. $(\%)$ & 0.64 & 5.40 & 1.35 & & \\
\hline \multicolumn{6}{|l|}{ Eusolex $^{\circledR} 6007$} \\
\hline Control & $49.00 \pm 0.81 \mathrm{a}$ & $3.98 \pm 0.43 \mathrm{a}$ & $99.80 \pm 0.11 \mathrm{a}$ & & \\
\hline 0.5 & $46.25 \pm 0.62 \mathrm{a}$ & $2.46 \pm 0.53 \mathrm{a}$ & $99.80 \pm 0.00 \mathrm{a}$ & 81 & Compatible \\
\hline 1.0 & $46.25 \pm 0.85 \mathrm{a}$ & $2.44 \pm 0.65 \mathrm{a}$ & $99.80 \pm 0.11 \mathrm{a}$ & 81 & Compatible \\
\hline 2.0 & $46.25 \pm 0.85 \mathrm{a}$ & $1.60 \pm 0.58 \mathrm{a}$ & $99.73 \pm 0.06 \mathrm{a}$ & 76 & Compatible \\
\hline 4.0 & $46.25 \pm 0.47 \mathrm{a}$ & $2.13 \pm 0.56 \mathrm{a}$ & $99.63 \pm 0.20 \mathrm{a}$ & 77 & Compatible \\
\hline 6.0 & $41.75 \pm 1.49 \mathrm{~b}$ & $2.24 \pm 0.60 \mathrm{a}$ & $99.73 \pm 0.06 \mathrm{a}$ & 74 & Compatible \\
\hline 8.0 & $45.00 \pm 0.40 \mathrm{ab}$ & $1.71 \pm 0.28 \mathrm{a}$ & $99.80 \pm 0.11 \mathrm{a}$ & 72 & Compatible \\
\hline F Test & $6.40 * *$ & $1.91^{\mathrm{NS}}$ & $0.20^{\mathrm{NS}}$ & & \\
\hline C.V. $(\%)$ & 0.88 & 7.55 & 1.80 & & \\
\hline
\end{tabular}

Means ( \pm standard error) with original values, but statistical analysis of growth and sporulation performed with data transformed in $\log (x+5)$ and analysis of germination performed with data transformed in $\operatorname{arc} \sin \sqrt{ } x / 100$. Means followed by the same letter, in the column, do not differ using the Tukey test $(\mathrm{p} \geq 0.05) .{ }^{\text {NS }}$ Non-significant; ${ }^{*}$ Significant at $5 \%$ probability; Significant at $1 \%$ probability. $\mathrm{CV}$.: coefficient of variation. 
Conidia germination was not affected by the photoprotectants, however, vegetative growth and sporulation decreased as the concentration increased, for most products. Neo Heliopan ${ }^{\circledR}$ E 1000 had greater deleterious effect on the fungus, because it reduced vegetative growth from the lowest concentration tested, continuing such reduction as product concentration increased. Sporulation was less affected by the photoprotectant, and at only two concentrations (6 and 10\%) conidia production was lower $(\mathrm{P} \leq 0.01)$ than that obtained in the control (Table 2). Neo Heliopan ${ }^{\circledR}$ BB acted differently on the fungus. Sporulation was the most affected parameter; in the control the fungus produced $2.50 \mathrm{x}$ $10^{9} \mathrm{con}^{\mathrm{col}}{ }^{-1}$, while in the highest concentration tested, the number of conidia formed was significantly lower $\left(\begin{array}{lllll}0.65 & \mathrm{x} & 10^{9} & \mathrm{con} . & \mathrm{col}^{-1}\end{array}\right)$. Vegetative growth was less influenced by the product than sporulation, and only at concentrations of 4 and $6 \%$ was there a reduction in growth $(59.75$ and $58.75 \mathrm{~mm}$, respectively), statistically differing from the control (64.25 mm) (Table 2).

Neo Heliopan ${ }^{\circledR}$ AV showed some effect on fungus growth and sporulation and Eusolex ${ }^{\circledR} 6007$ had little influence on growth. However, in most of the concentrations tested, the photoprotectants did not substantially affect fungus performance when compared with the control, and were, therefore, classified as compatible with JAB 68 at all concentrations (Table 2).

Some authors used conidia germination (HEDIMBI et al., 2008; SANTOS et al., 2011) or colony forming units analysis (INGLIS et al., 1995) to evaluate the compatibility of $M$. anisopliae with liposoluble photoprotectants. They found that the photoprotectants have little or no effect on the fungus, a fact that was also observed for germination of the $M$. anisopliae JAB 68 isolate. To exert pathogenic activity, after its germination, the fungus grows in the body of the insect and sporulates on its corpse. In addition to germination, the methodology used in this study to evaluate the compatibility of the fungus with the photoprotectants also include the analysis of growth and sporulation. To grow and sporulate, the fungus had to use the oil containing the liposoluble photoprotectants as a carbon source. The results showed that vegetative growth and sporulation were affected by the photoprotectants. Eusolex ${ }^{\circledR} 6007$ and NeoHeliopan ${ }^{\circledR}$ AV effect on these parameters was lower and the photoprotectants were considered compatible with the fungus, but with Neo Heliopan ${ }^{\circledR}$ BB and Neo Heliopan ${ }^{\circledR}$ E 1000, the effect was greater and the products were classified as moderately toxic in several concentrations.

\section{The effect of liposoluble photoprotectant on Metarhizium anisopliae conidia subjected to solar radiation}

The germination of conidia exposed to radiation from the solar simulator was influenced by the photoprotectants and concentrations used. The exposure period used to irradiate these suspensions also influenced germination (Table 3 ).

$M$. anisopliae conidia exposed to radiation from the solar simulator, with photoprotectant-free vegetable oil as its carrier, reduced germination from 1 hour of exposure. Germination decreased gradually with the increase of the exposure period, but even after five, six and seven hours of exposure, high percentages of germinated conidia (78.12, 42.90 and $42.70 \%$, respectively) were observed (Table 4). These results show that the vegetable oil is able of conferring protection to the fungus conidia, a fact that was also verified by SANTOS et al. (2011) for B. bassiana conidia. Similarly, POSADAS et al. (2012) reported that B. bassiana conidia exposed to UVB radiation showed greater tolerance when they mixed in vegetable oil before exposure. M. anisopliae conidia mixed in peanut oil and in Natur'l óleo ${ }^{\circledR}$ and Ashlade ${ }^{\circledR}$ emulsifiable oils were less susceptible to UV radiation (ALVES et al., 1998). The palm oil conferred high protection to M. anisopliae conidia after 12 hours of exposure to UVB radiation (LOONG et al., 2013).

The addition of any of the photoprotectants to the oily suspension, at any of the concentrations tested, increased conidia germination. The photoprotective effect was observed after 1 hour of exposure to radiation from the solar simulator and remained until 7 hours of exposure (Table 4). With solar simulator of the same model used in this study, an adjusted potency of $1,000 \mathrm{~J} \mathrm{~s}^{-1}$, HUNT et al. (1994) found that 16 liposoluble photoprotectants used at $1 \%$ concentration, conferred protection to the conidia of two $M$. anisopliae isolates, promoting high germination in relation to the control. However, after five hours of exposure, only Eusolex ${ }^{\circledR} 8021$ kept the photoprotective effect. 
Table 3. Effect of liposoluble photoprotectant on conidia of JAB 68 isolate of Metarhizium anisopliae exposed to radiation from a solar simulator during various periods of exposure.

\begin{tabular}{|c|c|}
\hline Treatments - concentrations & Germinated conidia (\%) \\
\hline Control & $80.04 \mathrm{e}$ \\
\hline Neo Heliopan $\mathrm{BB}^{\circledR} 0.5 \%$ & $96.24 \mathrm{bc}$ \\
\hline Neo Heliopan $\mathrm{BB}^{\circledR} 1.0 \%$ & $96.15 \mathrm{bc}$ \\
\hline Neo Heliopan $\mathrm{BB}^{\circledR} 2.0 \%$ & $95.55 \mathrm{c}$ \\
\hline Neo Heliopan A.V. ${ }^{\circledR} 0.5 \%$ & $99.14 \mathrm{a}$ \\
\hline Neo Heliopan A.V. ${ }^{\circledR} 1.0 \%$ & $99.07 \mathrm{a}$ \\
\hline Neo Heliopan A.V. ${ }^{\circledR} 2.0 \%$ & $99.35 \mathrm{a}$ \\
\hline Eusolex $6007^{\circledR} 0.5 \%$ & $94.45 \mathrm{~d}$ \\
\hline Eusolex $6007^{\circledR} 1.0 \%$ & $96.41 \mathrm{~b}$ \\
\hline Eusolex $6007^{\circledR} 2.0 \%$ & $96.68 \mathrm{~b}$ \\
\hline F teste & $1116.81 * *$ \\
\hline 1.s.d. $(\%)$ & 0.8107 \\
\hline S.E.M & 0.1680 \\
\hline \multicolumn{2}{|l|}{ Periods of exposure (hours) } \\
\hline 0.0 & $98.77 \mathrm{a}$ \\
\hline 0.5 & $98.59 \mathrm{a}$ \\
\hline 1.0 & $97.85 \mathrm{~b}$ \\
\hline 2.0 & $96.95 \mathrm{c}$ \\
\hline 3.0 & $97.09 \mathrm{c}$ \\
\hline 4.0 & $95.99 \mathrm{~d}$ \\
\hline 5.0 & $94.75 \mathrm{e}$ \\
\hline 6.0 & $89.66 \mathrm{f}$ \\
\hline 7.0 & $88.12 \mathrm{~g}$ \\
\hline F teste & $562.48 * *$ \\
\hline 1.s.d. $(\%)$ & 0.7211 \\
\hline S.E.M & 0.1629 \\
\hline Interaction & $168.72 * *$ \\
\hline C. V. (\%) for group & 1.05 \\
\hline C. V. (\%) for sub-group & 1.08 \\
\hline
\end{tabular}

Means followed by the same letter, in the column, do not differ using the Tukey test $(\mathrm{p} \geq 0.05)$. ** Significant at $1 \%$ probability. 1.s.d.: least significant difference. C.V..: coefficient of variation. S.E.M.: standard error mean. 


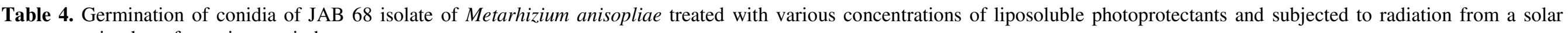
simulator for various periods.

\begin{tabular}{|c|c|c|c|c|c|c|c|c|c|c|c|}
\hline \multirow{3}{*}{$\begin{array}{l}\text { Radiatione } \\
\text { exposure } \\
\text { (hours) }\end{array}$} & \multicolumn{10}{|c|}{ Germination (\%) of conidia treated with concentrations of photoprotectants } & \multirow[t]{3}{*}{ F test } \\
\hline & \multirow[t]{2}{*}{ Control } & \multicolumn{3}{|c|}{ Neo Heliopan ${ }^{\circledR} \mathrm{BB}$} & \multicolumn{3}{|c|}{ Neo Heliopan ${ }^{\circledR}$ A.V. } & \multicolumn{3}{|c|}{ Eusolex $^{(} 6007$} & \\
\hline & & $0.5 \%$ & $1.0 \%$ & $2.0 \%$ & $0.5 \%$ & $1.0 \%$ & $2.0 \%$ & $0.5 \%$ & $1.0 \%$ & $2.0 \%$ & \\
\hline 0.0 & 98.97abA & $97.22 \mathrm{bA}$ & $97.02 \mathrm{bA}$ & $96.87 \mathrm{bA}$ & $99.85 \mathrm{aA}$ & $99.17 \mathrm{abAB}$ & $99.72 \mathrm{aA}$ & $99.67 \mathrm{aA}$ & $99.57 \mathrm{aA}$ & $99.67 \mathrm{aA}$ & $5.72 * *$ \\
\hline 0.5 & $97.97 \mathrm{aA}$ & $97.62 \mathrm{abcA}$ & $97.17 \mathrm{bcA}$ & $96.85 \mathrm{cA}$ & $99.57 \mathrm{aA}$ & 99.32abA & $99.60 \mathrm{aA}$ & 99.32abA & $99.20 \mathrm{abA}$ & 99.32abAB & $4.34 * *$ \\
\hline 1.0 & $93.32 \mathrm{~dB}$ & $97.52 \mathrm{abcA}$ & $97.05 \mathrm{bcA}$ & $95.55 \mathrm{cdAB}$ & $99.50 \mathrm{aA}$ & $99.42 \mathrm{aA}$ & $99.47 \mathrm{aA}$ & 98.87abA & 98.77abAB & 99.07abAB & $15.89 * *$ \\
\hline 2.0 & $90.50 \mathrm{dC}$ & $97.45 \mathrm{abcA}$ & $96.85 \mathrm{bcA}$ & $95.40 \mathrm{cAB}$ & $97.57 \mathrm{abcA}$ & $96.92 \mathrm{bcB}$ & $99.40 \mathrm{aA}$ & $98.42 \mathrm{abA}$ & $98.45 \mathrm{ab} A B$ & 98.52abABC & $24.22 * *$ \\
\hline 3.0 & $90.02 \mathrm{eC}$ & $97.07 \mathrm{bcdA}$ & $96.92 \mathrm{cdA}$ & $95.30 \mathrm{dAB}$ & $99.45 \mathrm{aA}$ & $99.40 \mathrm{aA}$ & 99.37abA & 97.70abcA & $97.65 \mathrm{abcABC}$ & 98.00abcABC & $29.78 * *$ \\
\hline 4.0 & $85.85 \mathrm{dD}$ & $96.72 \mathrm{bAB}$ & $96.17 \mathrm{bAB}$ & $95.55 \mathrm{bcAB}$ & $99.27 \mathrm{aA}$ & $99.27 \mathrm{aA}$ & $99.32 \mathrm{aA}$ & $93.80 \mathrm{cB}$ & $96.82 \mathrm{bBC}$ & 97.12abBC & $60.19 * *$ \\
\hline 5.0 & $78.12 \mathrm{dE}$ & $96.70 \mathrm{bAB}$ & $95.92 \mathrm{bABC}$ & $95.00 \mathrm{bAB}$ & $99.07 \mathrm{aA}$ & $99.45 \mathrm{aA}$ & $99.12 \mathrm{aA}$ & $91.92 \mathrm{cB}$ & $95.62 \mathrm{bC}$ & $96.62 b C$ & $148.86 * *$ \\
\hline 6.0 & $42.90 \mathrm{dF}$ & $94.75 \mathrm{bB}$ & $94.47 \mathrm{bBC}$ & $94.92 \mathrm{bAB}$ & $99.15 \mathrm{aA}$ & $99.40 \mathrm{aA}$ & $99.27 \mathrm{aA}$ & $86.05 \mathrm{cC}$ & $93.07 \mathrm{bD}$ & $92.65 \mathrm{bD}$ & $1083.03 * *$ \\
\hline $\begin{array}{l}\text { F teste } \\
\text { S.E.M. }\end{array}$ & $1826.29 * *$ & $16.74 * *$ & $5.75 * *$ & $2.46^{*}$ & $1.64^{\mathrm{NS}}$ & $2.48^{*}$ & $0.24 \mathrm{NS}$ & $130.19 * *$ & $48.05 * *$ & $47.10^{* *}$ & 0.5151 \\
\hline
\end{tabular}


Among the photoprotectants evaluated in this study, NeoHeliopan ${ }^{\circledR}$ AV provided the greatest protection to the conidia. Considering the three concentrations tested and all periods of exposure, germination of the conidia was greater than $99 \%$, except on 4 occasions. After 7 hours of exposure, germination of the conidia remained high, at 98.82, 99.32 and $98.87 \%$, in concentrations of $0.5,1$ and $2 \%$, respectively. B. bassiana conidia exposed for 2 hours to natural solar radiation in the region of Petrolina, in the Brazilian semi-arid region, under the effects of Neo Heliopan ${ }^{\circledR}$ AV, showed germination of $41 \%$ (SANTOS et al., 2011). The Neo Heliopan ${ }^{\circledR}$ BB photoprotectant also showed efficient conidia protection, especially at concentrations of 1 and $2 \%$. Of the three products tested, Eusolex ${ }^{\circledR} 6007$ showed the lowest photoprotective effect, but even so, gave high protection to conidia, because after 7 hours of exposure the germination was $88.6 \%$ when it was used the $1 \%$ concentration of the photoprotectant (Table 4).

Similar studies were conducted by other authors, but it is not always possible to compare the results because of differences in methodology and fungi used. B. bassiana conidia suspended in oil containing Eusolex ${ }^{\circledR} 8020$ were not protected after three hours of exposure to UVB radiation (INGLIS et al., 1995). Conidia of $M$. anisopliae formulated in oil containing Everysun ${ }^{\circledR}$ and E45 Sun Block $50^{\circledR}$ photoprotectants and exposed to radiation of $200-$ $400 \mathrm{~nm}$ (UV) for 5 hours, showed greater germination ( $29 \%$ and $40 \%$, respectively) than those only suspended in oil (4\%) (HEDIMBI et al., 2008).

Solar radiation is one of the main environmental factors that limits or compromises the fungal efficiency as control bioagents. The results of this study showed that $M$. anisopliae is compatible with liposoluble photoprotectants and that adding them to the oily formulations enhances the protection of the conidia against the harmful effects of solar radiation, contributing to the efficiency of the fungus when applied in the field.

\section{ACKNOWLEDGEMENTS}

The authors thank to the Post-doctoral National Program - Coordination of the Improvement Higher Education Personnel (PNPDCAPES) for financial support, and to Dr. Alex Sandro Campos Maia for technical assistance related to the use of solar simulator.

RESUMO: O objetivo desse trabalho foi analisar a compatibilidade do isolado JAB 68 de Metarhizium anisopliae com fotoprotetores lipossolúveis e a fotoproteção conferida aos seus conídios. O fungo foi cultivado em meio contendo os fotoprotetores Neo Heliopan ${ }^{\circledR}$ BB, Neo Heliopan ${ }^{\circledR}$ E 1000, Eusolex ${ }^{\circledR}$ 6007, Neo Heliopan ${ }^{\circledR}$ AV em várias concentrações. O crescimento vegetativo, a esporulação e a germinação foram avaliados para determinar a compatibilidade. Conídios foram suspensos em óleo contendo os fotoprotetores compatíveis, em suas respectivas concentrações, e submetidos por 0 a 7 horas à luz de um simulador solar na potência de $1.000 \mathrm{~W} \mathrm{~m}^{-2}$. Neo Heliopan $\mathrm{BB}^{\circledR} \mathrm{e}$ Neo Heliopan ${ }^{\circledR}$ E 1000 foram compatíveis com M. anisopliae à $2 \%$ e 1\%, respectivamente. Eusolex ${ }^{\circledR} 6007$ e Neo Heliopan ${ }^{\circledR}$ AV foram compatíveis até $8 \%$ e $7 \%$, respectivamente. Conídios de $M$. anisopliae expostos à radiação do simulador solar, tendo óleo isento de fotoprotetor como veículo, apresentaram germinação de $78,12 \%$ após cinco horas. Adicionando-se qualquer fotoprotetor à suspensão oleosa de conídios a porcentagem de germinação foi sempre maior que a obtida no controle. Neo Heliopan ${ }^{\circledR} \mathrm{BB}$ a 1 e $2 \%$ e Neo Heliopan ${ }^{\circledR}$ AV a $0,5 \%$ incrementaram a germinação. Após 7 horas de exposição as porcentagens de germinação foram de 93,77, 94,55 e 98,82\%, respectivamente. Eusolex ${ }^{\circledR} 6007$ não foi tão eficiente quanto os produtos anteriores, mas no mesmo período de exposição foi capaz de proteger os conídios $(88,60 \%$ de germinação) quando usado na concentração de $1 \%$. A adição de fotoprotetores em formulações oleosas de M. anisopliae confere proteção aos raios UV, contribuindo com a eficiência do fungo no campo.

UV.

PALAVRAS-CHAVE: Controle microbiano. Fungo entomopatogênico. Luz solar. Fotoproteção. Radiação

\section{REFERENCES}

ALVES, R. T.; BATEMAN, R. P.; PRIOR, C.; LEATHER, S. R. Effects of simulated solar radiation on conidial germination of Metarhizium anisopliae in different formulations. Crop Protection, v. 17, p. 675-679, 1998. https://doi.org/10.1016/S0261-2194(98)00074-X 
ALVES, R. T.; BATEMAN, R. P.; GUNN, J.; PRIOR, C.; LEATHER, S. Effects of Different Formulations on Viability and Medium-Term Storage of Metarhizium anisopliae conidia. Neotropical Entomology, v. 31, p. 091-099, 2002.

BARBOSA, J. C.; MALDONADO, JR. W. AgroEstat: Sistema para Análises Estatísticas de Ensaios Agronômicos, Versão 1.0, 2010.

BATISTA FILHO, A.; ALVES, S. B.; AUGUSTO, N. T.; PEREIRA, R. M.; ALVES, L. F. A. Stability and Persistence of Two Formulations Containing Anticarsia gemmatalis Nuclear Polyhedrovirus (AgMNPV).

Neotropical Entomology, v. 30, p. 411-416, 2001. https://doi.org/10.1590/S1519-566X2001000300012

BUKHARI, T.; TAKKEN, W.; KOENRAADT, C. J. M. Development of Metarhizium anisopliae and Beauveria bassiana formulations for control of malaria mosquito larvae. Parasites \& Vectors, v. 4, p. 1-14, 2011. https://doi.org/10.1186/1756-3305-4-23

CABRAL, L. D. S.; PEREIRA, S. O.; PARTATA, A. K. Filtros Solares e Fotoprotetores mais Utilizados nas Formulações no Brasil. Revista Científica do ITPAC, v. 4, p. 1-10, 2011.

FONSECA, A.; PRISMA, L. N. Medicação Protetora. In: FONSECA, A.; PRISMA, L. N. (Eds.), Manual de Terapêutica Dermatológica e Cosmetologia. São Paulo. 2000.

GHAJAR, F.; HOLFORD, P.; COTHER, E.; BEATTIE, A. Enhancing survival and subsequent infectivity of conidia of potential mycoherbistats using UV protectants. Biocontrol Science and Technology, v. 16, p. 825839, 2006. https://doi.org/10.1080/09583150600700149

GALENA. Informe científico. available at: www.galena.com.br. 2007.

HEDIMBI, M.; KAAYA, G. P.; SINGH, S.; CHIMWAMUROMBE, P. M.; GINDIN, G.; GLAZER, I.; SAMISH, M. Protection of Metarhizium anisopliae Conidia from Ultra-violet Radiation and their Pathogenicity to Rhipicephalus evertsi evertsi ticks. Journal Experimental and Applied Acarology, v. 46, p. 149-156, 2008. https://doi.org/10.1007/s10493-008-9186-2

HYNES, R. K.; BOYETCHKO, S. M. Research initiatives in the art and science of biopesticide formulations. Soil Biology and Biochemistry, v. 38, p. 845-849, 2006. https://doi.org/10.1016/j.soilbio.2005.07.003

HUNT, T. R.; MOORE, D.; HIGGINS, P. M.; PRIOR, C. Effect of sunscrens, irradiance and resting periods on the germination of Metarhizium flavoviride conidia. Entomophaga, v. 39, p. 313-322, 1994.

https://doi.org/10.1007/BF02373036

INGLIS, G. D.; GOETTEL, M. S.; JOHNSON, D. L. Influence of Ultraviolet Light Protectants on Persistence of the Entomopathogenic Fungus, Beauveria bassiana. Biological Control, v. 5, p. 591-590, 1995. https://doi.org/10.1006/bcon.1995.1069

KAAYA, G. P. Laboratory and Weld evaluation of entomogenous fungi for tick control. Annals New York Academy Sciences, v. 916, p. 559-564, 2000. https://doi.org/10.1111/j.1749-6632.2000.tb05336.x

LOONG, C. Y.; SAJAP, A. S.; NOOR, H. M.; OMAR, D.; ABOOD, F. Effect of UV-B and Solar Radiation on the Efficacy of Isaria fumosorosea and Metarhizium anisopliae (Deuteromycetes: Hyphomycetes) for Controlling Bagworm, Pteroma pendula (Lepidoptera: Psychidae). Journal of Entomology, v. 10, p. 53-65, 2013. https://doi.org/10.3923/je.2013.53.65

MARANGA, R. O.; KAAYA, G. P.; MUEKE, J. M.; HASSANALI, A. Effects of combining the fungi Beauveria bassianaand Metarhizium anisopliae on the mortality of the tick Amblyomma variegatum (Ixodidae) in relation to seasonal changes. Mycopathologia, v. 159, p. 527-532, 2005. https://doi.org/10.1007/s11046005-3374-y 
MOCHI, D. A.; MONTEIRO, A. C.; SIMI, L. D.; SMAPAIO, A. A. M. Susceptibility of adult and larval stages of the horn fly, Haematobia irritans, to the entomopathogenic fungus Metarhizium anisopliae under field conditions. Veterinary Parasitology, v. 166, p. 136-143, 2009. https://doi.org/10.1016/j.vetpar.2009.07.037

MOCHI, D. A.; MONTEIRO, A. C.; MACHADO, A. C. R.; YOSHIDA, L. Efficiency of entomopathogenic fungi in the control of eggs and larvae of the horn fly Haematobia irritans (Diptera: Muscidae). Veterinary Parasitology, v. 167, p. 62-66, 2010a. https://doi.org/10.1016/j.vetpar.2009.09.046

MOCHI, D. A.; MONTERIO, A. C.; MACHADO, A. C. R.; YOSHIDA, L. Entomopathogenic fungal activity against pupae and adult Haematobia irritans (Diptera: Muscidae). Veterinary Parasitology, v. 168, p. 105110, 2010b. https://doi.org/10.1016/j.vetpar.2009.10.002

POSADAS, J. B.; MARCIEL, A. L.; MINI, J. I.; LECUONA, R. E. Natural tolerance to UV-B and assessment of protoprotectants in conidia of six native isolates of Beauveria bassiana (Bals-Criv) vuillemin. World Applied Sciences Journal, v. 20, p. 1024-1030, 2012.

PONTECORVO, G.; ROPER, J. A.; HEMONDS, L. M.; MCDONALD, K. D.; BUFTON, A. W. J. The genetics of Aspergillus nidulans. Advances in Genetics, v. 5, p. 141-238, 1953. https://doi.org/10.1016/S00652660(08)60408-3

ROSSI-ZALAF, L. S.; ALVES, S. B.; LOPES, R. B.; SILVEIRA NETO, S.; TANZINI, M. R. Interação de Microrganismos com Outros Agentes de Controle de Pragas e Doenças, in: ALVES, S. B.; LOPES, R. B. (Eds.). Controle microbiano de pragas na América Latina: avanços e desafios. Piracicaba. 2008, p. 210302.

SANTI, L.; SILVA, L. A. D.; SILVA, W. O. B.; CORREA, A. P. F.; RANGEL, D. E. N.; CARLINI, C. R.; SCHRANK, A.; VAINSTEIN, M. H. Virulence of the entomopathogenic fungus Metarhizium anisopliae using soybean oil formulation for control of the cotton stainer bug, Dysdercus peruvianus. World Journal Microbiology and Biotechnology, v. 27, p. 2297-2303, 2011. https://doi.org/10.1007/s11274-011-0695-5

SANTOS, P. de S.; SILVA, M. A. Q.; MONTEIRO, A. C.; GAVA, C. A. T. Improving Photoprotection of Beauveria bassiana Conidia for Biological Control of the Cactus Pest Dactylopius opuntiae in the Semiarid Region Northeast of Brazil. Biocontrol Science and Technology, v. 21, p. 893-902, 2011. https://doi.org/10.1080/09583157.2011.586022 